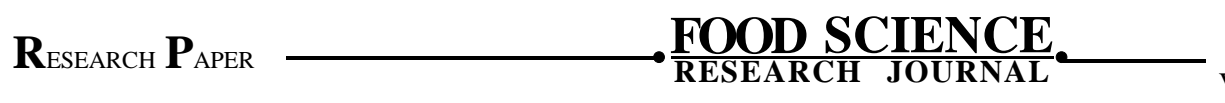

www.researchjournal.co.in
Volume $7 \mid$ Issue $2 \mid$ October, 2016 | 165-169
DOI : 10.15740/HAS/FSRJ/7.2/165-169

\title{
Preparation of Kulfi with incorporation of mango pulp
}

\author{
Rohini Darade, Seema Chaudhary and V.G. AtKare
}

The good quality Kulfi mix prepared with 37 per cent of milk ( $4.5 \%$ fat and $8.5 \%$ SNF), 30 per cent cream ( $35.5 \%$ fat and $5.5 \% \mathrm{SNF}), 6$ per cent skim milk powder, $(0.5 \%$ fat and $99 \% \mathrm{SNF}), 15$ per cent sugar, 0.5 per cent stabilizer (gelatin). Overall acceptability of Kulfi prepared with 15 per cent mango pulp was significantly superior and more acceptable than other treatments. The chemical composition showed that in term of percentage fat, protein and total solids decreased while acidity increased with increasing mango pulp. In respect of physical properties, melting time of mango Kulfi increased and hardeness of Kulfi decreased with increasing level of mango pulp.

Key Words : Kulfi, Mango pulp, Sensory attributes, Chemical analysis

How to cite this article : Darade, Rohini, Chaudhary, Seema and Atkare, V.G. (2016). Preparation of Kulfi with incorporation of mango pulp. Food Sci. Res. J., 7(2): 165-169, DOI : 10.15740/HAS/FSRJ/7.2/165-169.

Author for correspondence :

ROHINI DARADE, Department of Animal Husbandry and Dairy Sciences,

College of Agriculture (Dr. P.D.K.V.), NAGPUR (M.S.) INDIA

Email : darade.rohini@gmail.com

Associate Authors' :

SEEMA CHAUDHARY AND V.G. ATKARE, Department of Animal Husbandry and Dairy Sciences, College of Agriculture (Dr. P.D.K.V.), NAGPUR (M.S.) INDIA 